\title{
THEORETICAL AND METHODOLOGICAL APPROACHES TO CONSTRUCTION OF SYSTEM RISK MANAGEMENT BY AGRICULTURAL SECTOR ENTERPRISES
}

\section{Kyrychenko N. V.}

\section{INTRODUCTION}

Currently, the agricultural sector has the most risky area of activity. The risks of agricultural enterprises are the subject of scientific research, as they have a huge impact not only on the activities of economic entities, but also on the food security of the state as a whole. Conditions for the functioning and development of agricultural enterprises are quite specific, which are not typical of other industries, it is dependent on natural conditions, seasonality of production, the complexity of innovation, regional, sectorial, functional, technological, organizational factors and features of living organisms in the production process ${ }^{1}$. It should be noted that mostly general principles of management of enterprises and production in conditions of uncertainty and risk are presented in the domestic and foreign economic literature. However, the conceptual and methodological foundations of identifying, analyzing and overcoming risks in the activities of agricultural enterprises are presented only in fragments. In the economic literature, insufficient attention is paid to the study of the methodological foundations of the risk management system in the agricultural sector, as well as modeling, forecasting and risk management, mostly research in this area relates to financial institutions. In this regard, there is an urgent need to define and develop a concept of risk management, which would take into account existing scientific advances, taking into account the specifics of the agricultural sector. In developing an effective methodological approach, it is also equally important to improve the classification of risks in agriculture for a better understanding of them. A sufficient number of scientific works of domestic and foreign scientists are devoted to the problems of determining economic risks and their classification. Among them are E. Altman, K. Baldin, K. Golovach, F. Knight, J. Keynes, L. Tepman, M. Tugan-Baranovsky, V. Khokhlov, J. Schumpeter and others. V. Ambrosov, R. Bilovol, M. Demyanenko, V. Grosul, I. Epifanova, O. Zaitseva, P. Makarenko, O. Tereshchenko and others devoted

${ }^{1}$ Tanklevska N.S. and Kyrychenko N.V. (2015), Aktyvizatsiia ta efektyvnist vprovadzhennia innovatsij ahrarnymy pidpryiemstvamy [Activation and efficiency of introduction of innovations by agrarian enterprises: monograph]. Hrin D.S. Kherson, Ukraine. 216 p. 
their works to the study of theoretical and applied principles of risk management of enterprises. But so far, despite the significant number, thoroughness and complexity of research, some issues focused on the development of effective tools and mechanisms for predicting the risks of their classification in the operation and development of agricultural enterprises in the economic literature have not received unequivocal opinions. This is what led to the choice of tasks and objectives of this study, which consist in improved classification of risks and in-depth theoretical and methodological principles of identification, analysis and overcoming them in the agricultural sector.

\section{Theoretical foundations and classification of risks of agricultural enterprises}

The lack of unity in the interpretation of the essence of the concept of "risk of agricultural enterprises" makes it difficult to identify the crisis. According to O. Andrushko, this is mainly due to the fact that the crisis is a set of many crisis phenomena ${ }^{2}$. K. Tsapko emphasizes that "the crisis of the enterprise is an unplanned and undesirable, time-limited process that can significantly hinder or even prevent the operation of the enterprise" ${ }^{3}$. The crisis state of the enterprise evolves from manifestations of risk to the onset of crisis phenomena, which turn into a crisis situation and a state of risk and, in the absence of qualified management influence, ends with a critical point - bankruptcy. Manifestations of risk are deviations of actual performance indicators from the planned ones, which can cause significant changes in the functioning and condition of the enterprise. In turn, the crisis phenomenon is understood as the deterioration of certain indicators of the enterprise, which have a negative impact on the processes of its life and become a moment of exacerbation of contradictions that arise in the interaction of individual elements of the enterprise, both internally and externally ${ }^{3}$. If the destabilizing impact of external and internal factors of entrepreneurial activity intensifies (increase in number, increase their strength, especially for economic entities in the agricultural sector, which also depend on climatic and anthropogenic factors), and the risk management system does not have time to implement the necessary effective management decisions, the company begins to lose profits and sometimes property ${ }^{4}$.

${ }^{2}$ Andrushko O.B. (2005), Analysis of models of diagnostics of crisis state and threat of bankruptcy of the enterprise. Bulletin of the National University "Lviv Polytechnic": Collection of scientific works, Management and Entrepreneurship in Ukraine: Stages of Formation and Problems of Development. № 547, P. 9-21

${ }^{3}$ Tsapko K.O. (2012), Research of scientific approaches to definition and an estimation of a crisis condition of the enterprise. Development management. № 2. P. 173-176.

${ }^{4}$ Babina N.O. (2014), Anti-crisis financial controlling as a factor of economic security of the enterprise. Effective economics: electronic scientific professional publication. № 5. URL: www.economy.nayka.com.ua 
The main task of risk classification is to maximize the optimization of the presented information about risks as a basis for determining the use of certain methods and methods of managing them. To date, there is no general opinion on the selected features and principles of risk classification. They are mainly guided in their description by two principles: the specific content of each type and type of risk or the sphere of economic activity and their division into groups in order to manage them depending on the source and stage of occurrence and the possibility of using the method.

Risks by area of activity depending on the nature of the expected result are classified into two main groups: net and speculative. In turn, taking into account the relationship of risks, each group is divided into subgroups, species and varieties. This classification is necessary at the very beginning, at the stage of risk identification, as it represents a wide list of them and provides a basis for characterizing the possible consequences. However, despite the level of detail, it does not allow to identify and characterize all existing potential risks due to their inevitable duplication, which complicates the choice of general approach and method of management. And since the operating conditions of agricultural enterprises have specific features that are not inherent in other industries (depending on weather (climatic) conditions, seasonal nature, features of technology and specific means and forms of production), we believe that it is more appropriate to classify the risks of the agricultural sector dividing them into groups (Fig. 1).

\begin{tabular}{|l|}
\hline$\cdot$ By the source of occurrence \\
\hline$\cdot$ By the possibility of forecasting \\
\hline$\cdot$ By level of occurrence \\
\hline$\cdot$ By frequency of occurrence \\
\hline$\cdot$ By the degree of perception \\
\hline$\cdot$ By entrepreneurial activity \\
\hline$\cdot$ By area of origin \\
\hline$\cdot$ By type of damage \\
\hline$\cdot$ By object of origin \\
\hline$\cdot$ By the etiology of the threat \\
\hline
\end{tabular}

Fig. 1. Classification of risks of agricultural enterprises by groups 
The results of the proposed classification approach indicate the possibility of creating an original method by which the company can independently group their own risks, based on relatively clear definitions of individual risk groups, conditions and specifics of their activities. The main component of this method is the practical distribution of risks of an individual enterprise according to its own management system. Based on this approach, when considering the risks of agricultural enterprises, we can identify eleven general groups, which in turn contain their own subgroups and can be grouped into separate categories (by area of activity of the enterprise). Thus, the group of risks identified by the terms of exposure can be divided into long-term, medium-term and short-term (single).

The classification feature of the division of business activities involves business and non-business risks, which indicates the differences between the types of activities that can be carried out by economic entities. Entrepreneurial risk is understood as the risk that arises as a result of financial and economic activities of the enterprise for profit, and in practice there are non-profit organizations (charitable foundations), which may also be affected by risk.

According to the degree of perception, the risks are divided into minimal (level of possible losses and negative consequences up to 20\%), acceptable (possibility of losses up to $40 \%$ ), unacceptable (characterized by the level of possible negative consequences up to $65-100 \%)$.

By the frequency risks are systemic (usually due to the system itself and the degree of their manifestation can't be reduced) and non-systemic (occur rarely and can be eliminated).

The level of risk also plays an important role in decisions about the choice of approaches and methods of managing them. According to this group, risks are divided into sectorial and intersectorail - depending on the field of activity, and in the agricultural sector can be divided into crop or livestock risks and operational (production) risks (micro level), regional (meso-level), state (macro level) and global.

According to the possibility of forecasting, risks can be divided into predictable (which can be predicted) and unpredictable (occur spontaneously due to force majeure).

According to the source, they depend on the factors of internal and external environment of the enterprise. In agriculture, it is also possible to identify risks that depend on the object of origin: crops grown and processed by the enterprise, the species of animals kept and the equipment and facilities of the agricultural enterprise. According to the etiology, the risks of the agricultural sector are classified into anthropogenic (depending on human impact) and natural (caused by natural forces). 
The following risks are distinguished by type of losses:

1. Material risks - costs that arise under unforeseen circumstances of the project or production plans, additional or direct costs of property, equipment, energy and resources.

2. Labor risks - usually associated with the cost of working time, labor, etc.

3. Financial risks - associated with the receipt of monetary damage caused by unforeseen payments (payment of fines), or non-repayment of debts, or non-receipt of funds for products sold, and so on. They are directly related to the financial activities of the enterprise (working capital financing; raising financial resources; investment financing; accumulation of receivables; accounting or tax accounting; loan servicing; placement of free financial resources and profit distribution). For a more convenient classification of types of financial risks, we propose to summarize them and present them in groups: credit; liquidity risks; investment; tax; planning risks.

The broadest classification of risks includes grouping by area of origin.

It should be noted that the risks of agricultural enterprises are very specific and due to the conditions of their management. The classification of risks of agricultural enterprises has a sectorial color and at the same time combines the generally accepted types of risks that are inherent in any business entity.

The proposed classification can be adapted and restructured for each individual enterprise depending on the case or situation in which it is located. For each task, the classification of risk can have an independent solution, as the nature of the risk is accompanied first by the type of activity and has its own specifics, which determines the appropriateness of the presence in the classification system of certain features. Based on the above, we can conclude that the proposed classification may be of practical interest to economic entities and be used as a model to create their own qualification table taking into account the sectorial characteristics of agricultural production and become one of the tools for management decisions to build an effective risk system of management at the enterprise.

\section{Methodical bases of construction of system of risk management at the enterprises of agrarian sector}

Specific features of the functioning of agricultural enterprises cause the presence of a significant number of risks, which in turn with a certain probability lead to the emergence of certain circumstances that adversely affect the activities and results of the industry. Thus, the first stage of risk assessment is to build a model of the market situation and determine its elements. In a risk situation, there are three main components: factors that 
affect the manifestation of risk, individual groups and types, and consequences of risks 5 .

In order for businesses to be able to quickly build the risk management process of their enterprise and organize appropriate departments to build a long-term risk management strategy, we propose to build a risk management system of an agricultural enterprise, which is an algorithm for organizing the risk management process based on clearly presented nature of risks, the place of the risk management system in the overall management system of the enterprise, a set of available tools for risk management and understanding the specifics of agricultural production when considering risk management ${ }^{6}$.

The proposed algorithm of integrated risk management contains five main stages:

1. Determining the feasibility of creating a risk management system (setting goals and objectives);

2. Identification of potential risks (information collection, classification and ranking of risks);

3. Risk assessment;

4. Selection and determination of methods of influence and coverage of risks;

5. Construction of a system for monitoring the effectiveness and adjustment of policies and procedures based on the results of monitoring (Fig. 2).

At the first stage of creating a risk management system it is necessary to first determine the feasibility of creating a risk management system, to determine the most suitable for the company type of system (centralized, decentralized, selective or complex), to form a budget for creating and using risk management system and identify its users. Effective implementation of the first stage will allow clearly formulating the requirements for the final product of the system, focusing on the most critical points and target orientation and saving resources.

The goals and objectives of risk management may vary depending on the type and specialization of the enterprise, but must be defined before the process of building systems begins.

Identification of potential risks is the second stage of the general algorithm of work with risks. This process includes: collecting information about the risks of the enterprise; formation of a tree (map) of enterprise risks; ranking of risks and their positioning within the enterprise, etc.

${ }^{5}$ Shamin D.V. (2020), The risk management system is a tool for the successful implementation of international megaprojects. Strategic decisions and risk management. Vol. 11(1), P. 98-103.

${ }^{6}$ Vasilenko V.A. (2005), Diagnostic system for sustainable development of enterprises. Culture of the peoples of the Black Sea region. № 66. P. 7-16. 


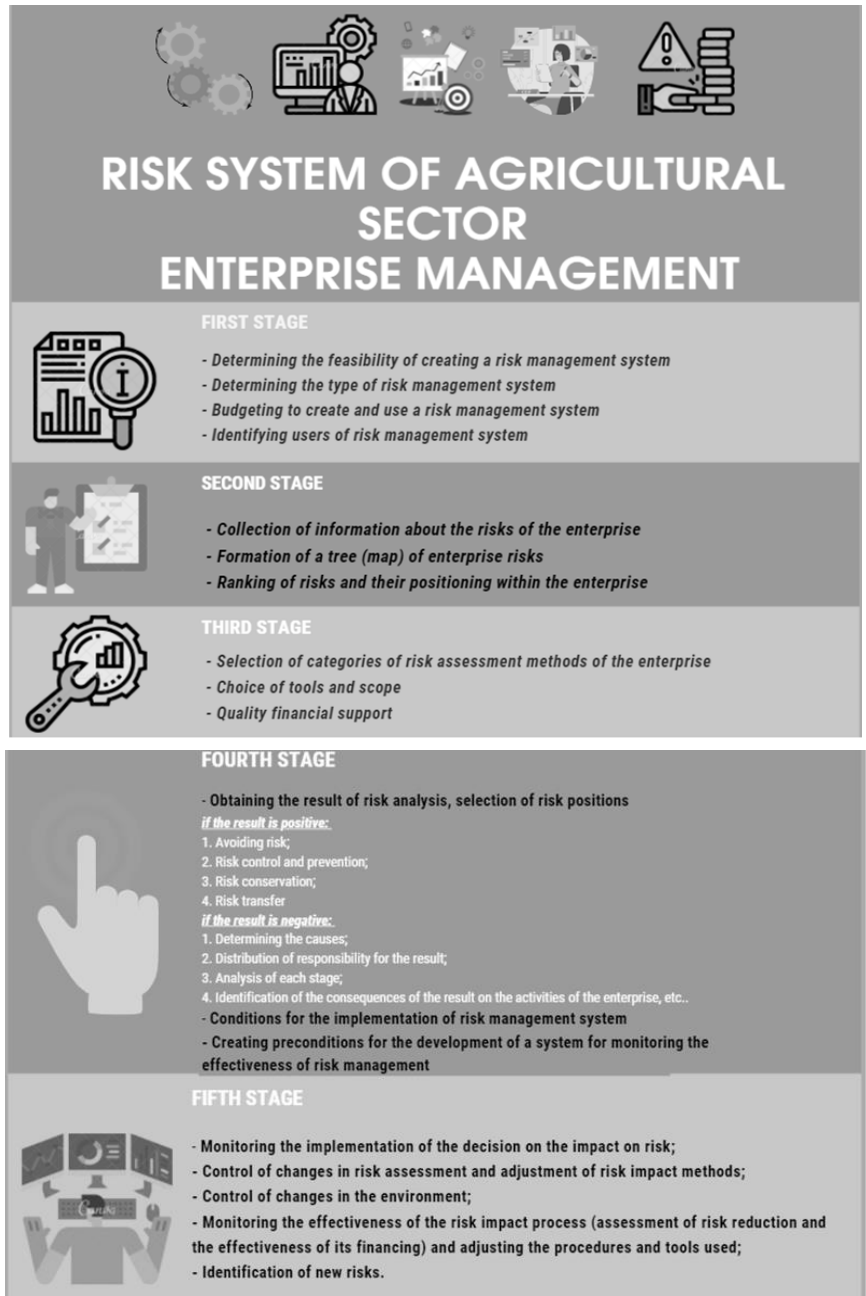

\section{Fig. 2 Algorithm for construction and operation of the risk management system of an agricultural enterprise}

Thus, according to the results of research presented in the previous section, we proposed an original approach by which the company can independently classify its own risks, based on relatively clear definitions of risk groups and the specifics of activities. The main element of this approach is the practical distribution of risks in the further direction of their management, i. e. the binding of the risk classifier to its own risk management system. 
Based on the proposed method of classifying risks by groups, we concluded that for easier identification and overcoming those risks by agricultural enterprises they should also be summarized in separate categories, and we surveyed more than 115 respondents from among agricultural professionals, representatives of medium and small business, as well as teachers of the Agricultural University. As a result of the expert assessment questionnaire, five generalized categories of risks and their consequences were identified (Table 1).

Table 1

Expert risk assessment of agricultural enterprises

\begin{tabular}{|c|c|}
\hline Risk category & Consequences \\
\hline 1 & 2 \\
\hline $\begin{array}{l}\text { Natural and climatic risks: } \\
\text { (agrometeorological events; } \\
\text { hydrogeological emergencies; } \\
\text { animal diseases; plant } \\
\text { diseases and lesions) }\end{array}$ & $\begin{array}{l}\text { Negative impact on the economic performance of } \\
\text { agricultural enterprises and reducing the } \\
\text { investment attractiveness of the industry; } \\
\text { damage, loss of property as a result of a natural } \\
\text { disaster; damage, death of crops or animals as a } \\
\text { result of natural factors or epidemics; forced } \\
\text { downtime or interruption of production due to } \\
\text { natural factors, etc. }\end{array}$ \\
\hline $\begin{array}{l}\text { Operational risks: } \\
\text { (production risks; logistics or } \\
\text { transport risks; environmental } \\
\text { risks; liability risks; } \\
\text { technological risks) }\end{array}$ & $\begin{array}{l}\text { Forced downtime or interruption of production } \\
\text { activities due to production factors; damage or } \\
\text { loss of the possibility of restoration of } \\
\text { agricultural machinery; increase in production } \\
\text { costs; increase in unit cost; unstable crop yields; } \\
\text { industrial safety and labor protection; risks } \\
\text { associated with the modernization of production } \\
\text { and innovation; damage or loss during } \\
\text { transportation of goods; environmental pollution; } \\
\text { reduction of soil fertility; increasing the level of } \\
\text { responsibility (financial sanctions), etc. }\end{array}$ \\
\hline $\begin{array}{l}\text { Financial risks: } \\
\text { credit risks; investment risks; } \\
\text { tax risks; planning risks; } \\
\text { liquidity risks) }\end{array}$ & $\begin{array}{l}\text { Negative impact on the financial support of } \\
\text { business structures; risk of loss of } \\
\text { competitiveness; reduction of investments in } \\
\text { fixed assets and technologies; lack of funds to } \\
\text { cover liabilities; errors in accounting and tax } \\
\text { accounting; non-fulfillment of the revenue } \\
\text { budget; exaggeration of current expenditures } \\
\text { over budget ones, etc. }\end{array}$ \\
\hline
\end{tabular}


Table 1 (ending)

\begin{tabular}{|c|c|}
\hline 1 & 2 \\
\hline $\begin{array}{l}\text { General business } \\
\text { (Business risks): } \text { (strategic } \\
\text { risks; commercial risks; legal } \\
\text { risks; personnel risks; } \\
\text { information risks; political } \\
\text { risks) }\end{array}$ & $\begin{array}{l}\text { Decreased profitability; gradual capture of } \\
\text { market share by competitors; aging processes; } \\
\text { lack of production capacity; stagnation of the } \\
\text { industry due to lack of highly qualified } \\
\text { personnel; reduction of the total rural population; } \\
\text { abuse of office, theft and fraud; loss of important } \\
\text { information and essential databases; lack of } \\
\text { information support for decision-making; } \\
\text { negative actions of competitors, etc. }\end{array}$ \\
\hline $\begin{array}{l}\text { Market risks: } \\
\text { (risks of changes in the value } \\
\text { of agricultural products; risks } \\
\text { of changes in the value of } \\
\text { materials, fuel, raw materials, } \\
\text { etc.; risks of changes in the } \\
\text { value of tariffs; interest rate } \\
\text { risks; currency risks) }\end{array}$ & $\begin{array}{l}\text { Negative impact of changes in the cost of } \\
\text { products, materials, tariffs on the economic and } \\
\text { financial results of agricultural enterprises; } \\
\text { increase in interest expenses on floating interest } \\
\text { rate loans; long-term increase in interest rates; } \\
\text { increase of operational currency risks, etc. }\end{array}$ \\
\hline
\end{tabular}

The above data show that natural and climatic risks and related adverse natural factors have a significant impact on the results of entrepreneurial activity in the agricultural sector. The main sources of climatic risks are adverse agrometeorological conditions (drought, frost, excessive rainfall, etc.), natural fires of all kinds, hydrological emergencies (floods, groundwater levels), infectious diseases of animals and plants. The stable influence of adverse natural and climatic factors has a negative impact on the production and economic performance of business structures of the agricultural sector and affects the investment attractiveness of the industry.

Operational risks are the risks of direct or indirect damage as a result of inadequate or ineffectively constructed production processes and systems, as well as the occurrence of catastrophic events related to the main production activities of the enterprise, i.e. the risks associated with the production activities of the organization and its software. We have identified the main operational processes of agricultural enterprises:

1) production and technological process (processing and production of finished products, cultivation of crop and livestock products, tillage, etc.);

2) the process of supplying raw materials (ensuring the production process);

3) logistics or transport processes;

4) processes of impact on the environment (internal and external), including the responsibility of enterprises to contractors and the environment. 
Financial risks ${ }^{7}$ include a wide range of risks (credit, tax, liquidity and planning risks, investment, etc.), this category is very significant for all industries, especially for the agricultural sector, these risks mostly have a negative impact on business support and may contribute to loss of competitiveness. It is advisable to pay special attention to investment risks, they provide for the possibility of deterioration of the financial position of the enterprise due to insufficient investment. Some agricultural enterprises have a shortage of financial resources, which in turn affects the ability to develop and improve production. Systematic financing of the investment process should consist in the organic unity of sources of financing of investment activities and investment methods. The methods of investment include: budget, credit, self-financing, as well as combined. The main sources of funding for enterprises in the agricultural sector are own funds, which can include retained earnings, depreciation and regional and state budgets. By attracting borrowed capital, companies increase investment risks. During the implementation of investment projects there may always be costs or force majeure. In addition, using borrowed funding sources, the company bears additional risks associated with debt service, which also increases the investment risk. One way to manage investment risk is to properly assess the most effective way to build up fixed assets, while assessing the conditions under which they are attracted and the cost associated with that financing. It is necessary to compare the net discounted income of the enterprise with different methods of financing.

In today's market, a huge threat and at the same time the greatest opportunities are corporate or business risks ${ }^{8}$. They are related to doing business. Depending on the specifics of the enterprise, the composition of these risks can be huge. The main negative consequences of this category include: reduced profitability, gradual seizure of market share by competitors, aging processes, lack of production capacity, stagnation of the industry due to low innovation and lack of highly qualified personnel, abuse of office, embezzlement and fraud, loss of important information and essential databases, lack of information support for decision-making and negative actions of competitors. Particular attention should be paid in this category to strategic risks that are manifested in the activities of enterprises and associated with the implementation of the strategy ${ }^{9}$. Strategic risks can

${ }^{7}$ Demianenko M. Ya. (2010), "Financial crisis in the agrarian sector of the agroindustrial complex", Ekonomichni nauky. Ceriia Oblik i finansy. vol. 7 (1), pp. 408-414.

${ }^{8}$ Granaturov V.M. and Litovchenko I.V. (2005), Upravlenie predprinimatelskimi riskami: voprosy teorii i praktiki [Business risk management: theory and practice]. MUP Jeven. Odessa. Ukraine.

${ }^{9}$ Klymenko S.M. and Dubrova O.S. (2005), Obhruntuvannia hospodarskykh rishen ta otsinka ryzykiv : navch. posib. [Establishment of state solutions and assessment of risiks]. KNEU. Kyiv. Ukraine. 
be divided into types: industry, technology, brand, competitive, customer, project, innovative, etc.

Respondents paid special attention to market risks, as they believe that they have a significant impact on the activities of enterprises, as they pose a threat associated with fluctuations in market factors, such as changes in the cost of raw materials or finished products, fuels, tariffs, adverse changes exchange rates or interest rates, etc.

The third stage of the algorithm for building a risk management system is their assessment. The study showed that in the modern economic literature there is a fairly wide range of methods for assessing individual risks, but for the most part they are usually focused on the activities of financial institutions. In particular, there are qualitative and quantitative methods of risk assessment.

Qualitative risk analysis is considered the most difficult stage of assessment, as it involves a wide range of general issues on which to find sources and causes of risk, identify and identify areas and types of risk, determine the practical benefits and possible negative consequences of work, processes or projects. Qualitative assessment, in most cases, focuses on the process of risk, which requires a rapid response. This risk assessment allows you to determine the degree of importance of the risk and choose ways to respond to it. Thanks to the existing information, it is possible to set priorities quickly and efficiently for different risk categories. Qualitative risk assessment of the organization can be carried out in the following areas: the nature of the business; due to the analysis of the external environment; management quality analysis; nature of activity; stability of work; stability of the financial condition of the enterprise ${ }^{10}$, etc.

Basically, qualitative risk analysis is conducted in two stages, according to which:

1. The expected positive results and possible negative consequences are compared.

2. The influence of the decisions made at the stage of strategy development is determined and the subjects for whom the occurrence of this or that risk will be beneficial are determined.

In practice, expert methods based on a subjective assessment of the expected parameters of activity are most often used for qualitative risk assessment. The most common method is the method of expert assessments, which provides the necessary information about the risks of the enterprise. This method is used in the analysis of problems that can't be formalized, due to lack of reliable information that would allow the use of more accurate and clear methods of assessing the level of risk.

${ }^{10}$ Makarenko I.O. (2005), "Algorithm for anti-crisis management of an enterprise". Aktualni problemy ekonomiky, vol. 3, pp. 104-109. 
As for quantitative methods, they involve risk assessment in absolute and relative terms. In absolute terms, the risk is measured by the frequency or size of possible losses in monetary terms. The most universal and common quantitative methods of risk analysis include: the method of expert assessments, the method of analogies, the decision tree method, statistical, analytical, rating methods and more. As a rule, in practice, several risk assessment methods are used to select the most optimal and acceptable option.

Conventionally, all the most commonly used techniques can be grouped into three categories:

1. Statistical - based on the analysis of statistical data using economic and mathematical modeling, mathematical statistics and probability theory. They are characterized by high accuracy of calculations, the ability to simulate different scenarios, but involve significant costs for obtaining information and analysis. And there is a possibility of risk in determining the adequacy of the selected model. In practice, it is most often used in the analysis of market and investment risks.

2. Analytical - based on the collection and objective analysis of information and decisions, based on a comprehensive analysis of both quantitative and qualitative indicators. They are characterized by the possibility of an individual set of indicators for analysis, are widely used, and allow achieving an objective assessment at a low cost, but due to a certain subjectivity of assessments, it is not always possible to measure some indicators. These methods are often used in the analysis of credit, operational and investment risks.

3. Experts - based on subjective analysis of quantitative characteristics using methodologies for ranking and comparing estimates. They have a fairly low cost and speed of results, do not require the collection of a huge amount of information. These methods still have a number of disadvantages, as they are highly dependent on the human factor (professional competence of the expert) and the difficulty of obtaining and calculating financial risk. Used in risk audit of production risks, in the compilation of risk maps and selected priorities.

The choice of methodology, tools and scope is determined by the tasks facing the expert who reviews the overall risk management strategy, as well as plans the budget for the risk management infrastructure.

At the fourth stage of our proposed algorithm of the risk management system of the agricultural enterprise, it is planned to choose the method of covering risks or influencing them and creating conditions for the development of a system for monitoring the effectiveness of risk management. Despite the large number of risk mitigation methods and tools that can be used, there are four main solutions in this area. Within the framework of these decisions, variations in the choice of instruments, degree of influence, etc. are 
possible, but in principle, when analyzing the risks, the manager must make the primary choice from the proposed positions.

1. Risk avoidance - the refusal of certain actions or decisions that are characterized by a high degree of risk.

2. Risk control and prevention - retention of risk with active influence on it by the enterprise, which is aimed at reducing the likelihood of risk or reducing the potential loss from the risk.

3. Risk conservation - used in cases where the level of risk is at an acceptable level, and the impact on it is not possible or economically unprofitable.

4. Transfer of risk - involves the transfer of risk to third parties in cases where the impact on it is not possible or economically unprofitable, and the level of risk exceeds the allowable level. Risk transfer is most often carried out through insurance, as well as through financial markets in the case of hedging, or through contractual arrangements.

The fifth final stage of the risk management process is the construction of a system for monitoring the effectiveness of management and adjusting policies and procedures based on the results of monitoring. The main objectives of this stage are to monitor the implementation of the decision on the impact on risk; control of changes in risk assessment and adjustment of risk impact methods; control of changes in the environment; monitoring the effectiveness of the risk impact process (assessment of risk reduction and the effectiveness of its financing) and adjusting the procedures and tools used; identification of new risks.

Within the framework of the proposed methodology, we pay great attention to the organizational aspects of building a risk management system of an agricultural enterprise, the timeliness of the organization of a structural unit for risk management. The analysis of the experience of agricultural enterprises has shown the urgent need and importance of organizing a decision-making system within the business entity on the basis of the proposed five-step algorithm for building an effective risk management system.

\section{CONCLUSIONS}

The agricultural sector is one of the most risky, so the economic activity of agricultural enterprises is always at risk due to specific operating conditions. Usually, managers of agricultural enterprises are reluctant to make decisions in risky situations, except when there is a likelihood of receiving certain income. As a rule, high income is directly associated with high risks. Therefore, there is a need (as far as possible) to manage risky situations that can be profitable. Risk management is a set of certain methods, techniques and measures used to identify, assess and, if necessary, influence the risks in order to reduce losses or increase profits. Entrepreneurs, risk managers, 
insurance specialists and other stakeholders can use various techniques and methods of management to exercise targeted influence on the objects of management (risks). At the same time, there is an urgent need for systematization and classification of risks by groups and improved methodological principles for identifying, analyzing and overcoming them in the agricultural sector.

The analysis of different approaches to the systematization and classification of risks and the effectiveness of their management allowed us to propose an original approach by which agricultural enterprises can independently classify their own risks, based on relatively clear definitions of risk groups and specifics. The main element of this approach is the practical distribution of risks in the further direction of management, ie the binding of the risk classifier to their own management system. Thus, eleven general and specific risk groups were identified, which are specific only to the agricultural sector.

Based on the proposed method of classifying risks by groups, we came to the conclusion that for more convenient identification and overcoming by agricultural enterprises, they should also be summarized in separate categories. According to expert surveys, the five most important risk categories for the agricultural sector and their consequences were identified. These included: 1) natural and climatic risks; 2) financial risks; 3) operational risks; 4) general business (business risks); 5) market risks.

Studies have shown that a well-established risk management system in the enterprise allows you to identify potentially possible situations associated with undesirable developments; obtain characteristics of possible losses (losses) or lost opportunities associated with adverse developments; take into account in decision-making significant organizational efforts, time and costs associated with risk assessment and rational impact on its level.

In order for businesses to be able to quickly build the risk management process of their enterprise and organize appropriate departments to build a long-term risk management strategy, we have proposed a risk management system for agricultural enterprises, which is an algorithm for organizing risk management process taking into account the specifics of agricultural production.

The proposed integrated risk management algorithm contains five main stages. At the first stage of the algorithm, it is proposed to determine the feasibility of creating a risk management system (set the goal, objectives, type of system, calculate the budget, etc.). The second stage involves identifying potential risks (collecting information about the risks of their classification and ranking). In the third stage, it is proposed to evaluate them. The importance of this stage, in our opinion, is characterized by the fact that the measures taken during it allow to obtain a certain result of both quantitative 
and qualitative nature, which will further affect the choice of methods of risk exposure and ultimately the effectiveness of the risk process. The assessment itself should be performed on the basis of the goals and information received, therefore, depends on the correctness of these actions. Thus, risk assessment occupies one of the key places in the risk management process and has a clear relationship with other stages of the process. Risk assessment at any agricultural enterprise can be performed according to its own methodology.

During the implementation of the fourth stage, the selection and determination of methods of impact and risk coverage is carried out. The last stage of the enterprise risk management algorithm requires the construction of a monitoring system to monitor the implementation of decisions, methods of influencing and adjusting risks, procedures and tools used, analysis of financing efficiency, and so on.

\section{SUMMARY}

The study examines the components of risk in the agricultural sector of the Ukrainian economy. The conceptual apparatus of the chosen topic is thoroughly analyzed. An original approach to the classification of risks, taking into account the specific conditions of agricultural enterprises, is proposed, which provides for the classification by groups and the most significant categories of risks for agricultural enterprises. The main element of this approach is the practical distribution of risks for further areas of their management, that is, linking the risk classifier to its own management system.

A methodology for organizing a decision-making system within an economic entity is proposed on the basis of a five-stage algorithm for constructing an effective risk management system. Within the framework of this methodology, considerable attention is paid to the organizational aspects of building a risk management system for an agricultural enterprise, guidelines are given for organizing a structural unit for risk management.

\section{REFERENCES}

1. Tanklevska N.S. and Kyrychenko N.V. (2015), Aktyvizatsiia ta efektyvnist vprovadzhennia innovatsij ahrarnymy pidpryiemstvamy [Activation and efficiency of introduction of innovations by agrarian enterprises: monograph]. Hrin D.S. Kherson, Ukraine. 216 p.

2. Andrushko O.B. Analysis of models of diagnostics of crisis state and threat of bankruptcy of the enterprise. Bulletin of the National University "Lviv Polytechnic": Collection of scientific works, Management and Entrepreneurship in Ukraine: Stages of Formation and Problems of Development. № 547. 2005. P. 9-21 
2. Tsapko K.O. Research of scientific approaches to definition and an estimation of a crisis condition of the enterprise. Development management. № 2. 2012. P. 173-176.

3. Babina N.O. Anti-crisis financial controlling as a factor in ensuring the economic security of the enterprise. Effective economics: electronic scientific professional publication. №5. 2014. URL: www.economy.nayka.com.ua

4. Shamin D.V. (2020), The risk management system is a tool for the successful implementation of international megaprojects. Strategic decisions and risk management. Vol. 11(1), P. 98-103.

5. Vasilenko V.A. (2005), Diagnostic system for sustainable development of enterprises. Culture of the peoples of the Black Sea region. № 66. P. 7-16.

6. Demianenko M. Ya. (2010), "Financial crisis in the agrarian sector of the agro-industrial complex", Ekonomichni nauky. Ceriia Oblik $i$ finansy. Vol. 7 (1), pp. 408-414

7. Granaturov V.M. and Litovchenko I.V. (2005), Upravlenie predprinimatelskimi riskami: voprosy teorii i praktiki [Business risk management: theory and practice]. MUP Jeven. Odessa. Ukraine.

8. Klymenko S.M. and Dubrova O.S. (2005), Obhruntuvannia hospodarskykh rishen ta otsinka ryzykiv: navch.posib. [Establishment of state solutions and assessment of risiks]. KNEU. Kyiv. Ukraine.

9. Makarenko I. O. (2005), "Algorithm for anti-crisis management of an enterprise”. Aktualni problemy ekonomiky, vol. 3, pp. 104-109.

Information about the author: Kyrychenko Natalia Valeriivna, $\mathrm{PhD}$ in Economics, Associate Professor at the Department of Management and Information Technologies Kherson State Agrarian and Economic University 23, Stritenska str., Kherson, Ukraine, 73006 orcid.org/0000-0003-1721-258X 